\title{
Presentation of the Steno Medal to Professor John H. Callomon, London, UK
}

FINN SURLYK

https://doi.org/10.37570/bgsd-1995-41-21

After nearly a whole day of scientific lectures, we will now proceed to ceremony - the award of the Steno Medal to Professor John H. Callomon. The medal is normally awarded every fifth year, but this year is special due to the 100 year anniversary of the society.

More than 300 years ago Steno formulated the first laws of stratigraphy and recognised the true nature of fossils as the remains of once living animals. A major contribution to geology within the fields treated in Steno's pioneering work thus falls within the fields of stratigraphy and palaeontology. If it is further considered that the contribution should be within a field of special interest to the Danish geological community one immediately thinks of Greenland, the area which internationally is almost synonymous with Danish geology. The combination of these four premises, a major contribution, stratigraphy, palaeontology, and Greenland essentially has one result, John Callomon.

John Callomon is a long time friend of Copenhagen geology. His introduction to science was, however, in a totally different field. In secondary school during the early forties he became attracted to chemistry. The teachers were not particularly inspiring for in war-time only the older ones were left behind. This is almost like the universities today, fortunately, however, for more peaceful reasons. But the teachers were experienced and the facilities were excellent. The emphasis was on inorganic chemistry. Curiosity aroused in school was supported by reading of chemistry texts available in the local public library. John found chemistry easy and interesting so it was natural to continue its study at university.

John then started out on his academic career at Oxford, where the system was based on personal tutorials, which meant that one leamed by reading and writing. And to the students present here today I may mention that this meant writing a weekly essay of 5000 words over 60 weeks in three years.

John's real engagement in science took off during a post-doc in Ottawa under Gerhard Herzberg, who was the leader of one of the world's grand laboratories in the field of molecular physics. The period in Ottawa was not only of major importance in terms of chemical and physical studies but also resulted in a long-time friendship with Hans Frebold, the great Jurassic stratigrapher who had worked in Germany, Denmark and with Lauge Koch in Greenland. This illustrates the importance and sometimes unexpected outcome of studying at institutes in other countries.

The introduction to geology did not come through the school, as this field was not taught in schools then, just like it is not taught in Danish schools today. Instead it was brought to him by a friend of the family who was a keen amateur geologist. Perhaps this type of introduction via the world of amateur geologists has led to John's view of geology as "an observational science that one can readily leam by oneself, the practical work consisting of little more than the study of outcrops, the equipment needed consisting of little more than a hammer, a lens, and perhaps a polarizing microscope". This attitude to geology gives some clues to certain aspects of John's reputation in geological circles. Most geologists present here today would not immediately recognise their daily work from that quote.

Shortly after the war John's interest in geology became more focused. The trigger was the appearance of Arkell's seminal book "The geology of Oxford" in 1947, which steered his geological activities into the Jurassic. This period has a detailed stratigraphy and biochronology based on ammonites, and Jurassic rocks are well exposed around Oxford, and could be reached on bicycle.

During his student years in Oxford he not only met Arkell, but also Desmond Donovan who had participated in several of Lauge Koch's expeditions to East Greenland. In casual conversation he leamed from Donovan that it might not be impossible to get to East Greenland in 1957. With short waming John received a "Yes, you can go to East Greenland". This association with Greenland and Danish geology has lasted ever since, and is the main reason for me standing here today presenting the Steno Medal to John Callomon.

John's first trip to East Greenland was by DC-4 to Mestersvig, followed by Catalina to Ella $\emptyset$ and finally by Norseman through the Stauning Alper to Milne Land, where the famous Upper Jurassic section was the target. They did not know what to find. Had Rosenkrantz collected all the ammonites? Was it possible to make modern collection bed-by-bed? Already the first days work took them by surprise. The wealth of material just lying there waiting to be picked up was unbelievable. John's role as a junior assistent shifted, however, rapidly. After three days in the field Donovan told him "By the way, the plane is coming to take me to Wollaston Forland to-day. 
You and your assistants will be supplied at weekly intervals, with camp-shifts as you need them. Have a good summer".

The season of 1958 was to be Koch's last in Greenland, and the division of Greenland into West Greenland which was GGU territory and East Greenland which was Lauge Koch territory came to a definitive end. This political decision created much bitterness and perhaps gave many foreign geologists who had participated in Koch's expeditions a somewhat biased view of Danish geology. This is also reflected in many of John's stories and impressions and also in his writings for example in the acknowledgements of his papers, where he more than 30 years later still lists his dept to Lauge Koch and co-workers from those days first.

Danish exploration of the Jurassic sections in Milne Land and Jameson Land after the end of the Koch era was resumed in 1968 by a group of geologists from the University of Copenhagen under the leadership of the late Tove Birkelund. The group worked in cooperation with GGU's big 5 year mapping program in the Scoresby Sund fjord region and was in late critical phase generously supported by the Carlsberg Foundation.

It is mainly due to the energetic efforts of Tove Birkelund that the stratigraphy of the sedimentary basin was unravelled, because GGU found - as I remember it - that it was sufficient from a mapping point of view to label the sedimentary section as "undifferentiated Mesozoic cover rocks". Interestingly the Mesozoic study is the only work from that period which is really well known internationally and which has attracted wide interest, especially of course from the oil industry.

The work of the University group rapidly became focused on the Jurassic succession. It was excellently exposed, highly fossiliferous at many levels, and thus of great interest in a period immediately preceeding the breakthrough of facies analysis and dynamic sedimentology. The group included university geologists supplemented with a few foreign workers, notably people who had been in the area earlier and thus could provide a link with the work undertaken during the Koch era. The two most prominent foreign participants in our work was John Callomon and Chris Birkenmajer from Poland who is also present here today.

John participated in the work almost from the beginning. He had undertaken the first detailed stratigraphic studies since the classical ammmonite monographs of Spath based mainly on the collections of Rosenkrantz and Aldinger from the twenties and thirties. He could thus guide us through the morass of Jurassic ammonite zones and local field stratigraphic terms. Sometimes of course supplemented with a conservatism concerning terminology and certain preconceived notions which are very well known from all expeditions with members who have participated in earlier work in the region.

Apart from this slight or apparent lack of appreciation of advances in understanding of the depositional environments and logical grouping of rocks into genetic units it was always big fun to work with John. I spent a period in a joint camp with John and Tove below the classical Jurassic locality, Katedralen, in Jameson Land in 1971. The work on the sections was illuminated by numerous discussions coloured by John's special attitude to the simplicity of geology in general and to the simplemindedness of geologists in particular, and Tove often looked sligthy frightened at us not fully realising if we were mad at each other or just having fun. I am not quite sure if she ever found out.

After the Jameson Land campaign was finished in the early seventies, John took part in Tove Birkelund's follow-up project which involved the study of the classical Upper Jurassic sections in Milne Land. This was to become the most productive part of their cooperation, and today Milne Land stands as a type section for the Boreal Upper Jurassic, and the biostratigraphic papers stand as milestones in Arctic research.

In addition to his work on the ammonite biostratigraphy of the Middle and Upper Jurassic of the Arctics, John has made profound contributions to ammonite taxonomy and to bio- and chronostratigraphic thinking. If the stratigraphic community had followed his simple biochronostratigraphic system we would have avoided the formalistic burden of more-or-less official bio-, litho- and chronostratigraphic codes, which killed stratigraphy as an active, interesting science. The death lasted for more than 20 years. Only recently has stratigraphy regained its role as one of the truly fundamental and highly dynamic geological disciplines by the introduction of sequence stratigraphy and related fields.

John is probably best known in wider palaeobiological circles for his recognition of sexual dimorphism in ammonites. This concept involving conspecific micro- and macroconchs previously assigned to different species or even genera, was met with much scepticism by classical ammonite taxonomers; but is today generally accepted.

The work on the biostratigraphy of the Middle Jurassic of Jameson Land was not finished before Tove Birkelund's death. With the onset of stratigraphical and sedimentological work in Jameson Land by my own group in the last few years the need of a concise biostratigraphic framework for sequence stratigraphical studies became very obvious. I therefore contacted John whom I had not seen for some years to hear if he was interested in taking it up again, and received an enthusiastic answer. This meant the renewal of an old friendship, and the introduction to the Ph.D. students of a key person in the field of Jurassic biostratigraphy.

John has now been back in Copenhagen several times within the last year or so to continue the work on the Middle Jurassic stopped by Tove's untimely death. His recent retirement from his professorship in chemistry at University College, London University, means that he can devote his time to real science instead of wasting it on some chemistry which just requires a mass spectrometer and a PC. And sure enough, a short while ago I received a letter from John asking if it was possible to go back to the 
old hunting fields around Katedralen. Typical for one who has participated in early Arctic field work and whose key experience is from the pre- or early high-tech era he wrote after expressing a few modest requests concerning logistical support: "I might be prepared to walk, as we did in 1958. But that would now be a little hard". I can assure you that the good cooperation between the Basin Studies Group at the University and the Oil section of the GGU already means that a visit to your old hunting grounds in Jameson Land in 1994 will be made possible.
John, it has been a great pleasure to have known you and worked with you over all these years. Your continued cooperation with Danish geology over 35 years since 1957 , and your outstanding and basic contributions to Jurassic biostratigraphy, Arctic geology and ammonite taxonomy makes you an obvious recipient of the Steno Medal. It is a great pleasure for me to have had to opportunity on behalf of the Geological Society of Denmark to express the Society's recognition of your achievements. 